\title{
A Pilot Study of User-requirements for Building Maintenance Systems in Malaysian Higher Education Institutions
}

\author{
Mohd Zulakhmar Zakiyudin ${ }^{1,}$, Mohamad Syazli Fathi ${ }^{2, b}$ \\ Shuib Rambat ${ }^{3, \mathrm{c}}$, Siti Uzairiah Tobi ${ }^{4, \mathrm{~d}}$ and Nor A'ini Rajab ${ }^{5, \mathrm{e}}$
}

\author{
${ }^{1}$ Twintech International University College of Technology, Sri Damansara Business Park, \\ Persiaran Industri, Bandar Sri Damansara 52200 Kuala Lumpur. \\ 2,3,4,5 UTM Razak School of Engineering \& Advanced Technology, Universiti Teknologi Malaysia, \\ Jalan Semarak, 54100 Kuala Lumpur, Malaysia. \\ a zulakhmar.fabe@twintech.edu.myb syazli@utm.my, 'shuibrambat@utm.my, duzairiah.kl@utm.my, \\ enorainirajab.kl@utm.my
}

Keywords: User-requirements; building maintenance management; higher education institution; facilities management; assets.

\begin{abstract}
Worldwide, the investment in building maintenance is huge as it represents almost $50 \%$ of the total turnover of construction activities. Building maintenance is also categorised as the commonest function listed in facilities management activities. This pilot study explores the current practice of building maintenance management in higher education institutions in Malaysia. Information gathered from semi-structured interviews focuses on different areas of building maintenance practices. The main issue is to identify the user-requirements. The areas of study are to cover the objectives of maintenance departments, maintenance reporting processes, maintenance verification processes and other associated tasks. In addition, this study also looks into the contributions of Information Technology (IT) facilities to maintenance practices. Based on the findings, there will be differences in the maintenance practices among the four universities; empirically, of the 57 elements studied only $30 \%$ were similar. Some strengths and weaknesses in the maintenance practices were identified and ways in which IT facilities could help to improve the situation. In the future it is envisioned that good building maintenance practices would be the norm in Malaysia to maximise the benefits that users could expect from their buildings and facilities.
\end{abstract}

\section{Introduction and background}

The European Committee for Standardisation (CEN) - ratified by the British Standard Institution (BSI) building maintenance code of practice - play a major role in facilities management activities as they help organizations to develop agreed services for buildings which support and improve the effectiveness of their primary activities [1]. In Malaysia the increasing awareness of the importance of a proper building maintenance and management system becomes the main contributing factor for the development of facilities management activities [2]. There are five main management issues in managing Malaysian government-owned property. Those issues are: lack of a proper property unit/department within a ministry, lack of expertise, lack of proper strategies, lack of proper management procedures and lack of IT usage [3]. A study of the maintenance practices in Malaysian higher education institutions found that the maintenance management systems are not IT-based and mainly carry out corrective and cyclical maintenance work. There are also no clear key performance indicators, maintenance tends to be budget-driven rather than needs-driven and is understaffed by inadequately qualified personnel [4]. This study is also influenced by the growth of mobile devices in recent years, that has transformed the way in which people and organisations communicate. It has also revolutionised the construction industry in the way in which information is exchanged and viewed [5] [6]. Before conducting a detailed study of all twenty Malaysian higher education institutions, this preliminary analysis involved four selected universities $(20 \%)$ as a pilot study. The main objective of this pilot study is to discover the user-requirements for effective building maintenance practices in Malaysian higher education institutions. As the main agenda, these user-requirements must be clearly identified and will be manipulated to form the main criteria 
for developing a mobile application later in this research. The four selected higher education institutions each have different criteria in terms of size, age and categories (Research University, Comprehensive University and Focused University). The results collected from this pilot study will identify the user-requirements and technology to be adopted. These user-requirements are very important in understanding the needs and concepts to be proposed in future research. The following sections discuss the methodology adopted in the pilot study, the maintenance practices in universities and user-requirements in building maintenance management processes followed by a cross-analysis, discussion and conclusion.

\section{Methodology}

The semi-structured interview was conducted with the officer directly involved in maintenance management practices under the maintenance department in each of the four selected higher education institutions. Four campuses out of the twenty Malaysian higher education institutions is an ideal number as a previous study recommended only $10 \%$ from the final study size [7][8]. The respondents could provide reliable and comparable qualitative data, which is among the advantages of conducting the semi-structured interviews [9]. These interviews benefit the researcher in many ways includes providing an opportunity to generate rich data that can be analysed in different ways. It also allows informants the freedom to express their views in their own terms [10] [11]. It was preagreed during the interview that the information would be confidential and that the name of the university would not be revealed. Thus, the higher education institutions are named as either University A, B, C or D.

\section{Maintenance Practice in Malaysian Higher Education Institutions}

Table 1 provides details about the maintenance practices, the supporting information and technology system followed by a cross-analysis of user-requirements in the maintenance management process in each university.

Table 1: Maintenance Practice in Universities A, B, C and D

\begin{tabular}{|l|l|l|l|l|}
\hline University & University A & University B & University C & University D \\
\hline $\begin{array}{l}\text { Maintenance } \\
\text { Department }\end{array}$ & $\begin{array}{l}\text { Development and } \\
\text { Maintenance } \\
\text { Department }\end{array}$ & $\begin{array}{l}\text { Facilities Management } \\
\text { Office }\end{array}$ & $\begin{array}{l}\text { Office of Asset \& } \\
\text { Development }\end{array}$ & $\begin{array}{l}\text { Development and } \\
\text { Maintenance } \\
\text { Department }\end{array}$ \\
\hline $\begin{array}{l}\text { Building } \\
\text { Implintenance } \\
\text { and Complaint System } \\
\text { (eFACT) }\end{array}$ & $\begin{array}{l}\text { E-Aduan supported by } \\
\text { Archibus under package } \\
\text { Web Central, Space } \\
\text { Management and } \\
\text { Building Operation } \\
\text { Management }\end{array}$ & $\begin{array}{l}\text { Electronic Customers } \\
\text { Support (eCS) }\end{array}$ & Manual \\
& $\begin{array}{l}\text { Walk-in, phone call \& } \\
\text { website }\end{array}$ & Phone call \& website & $\begin{array}{l}\text { Walk-in, formal letter, } \\
\text { phone call, fax and } \\
\text { email }\end{array}$ \\
\hline
\end{tabular}

\section{User-requirements in the Building Maintenance Management Process}

A cross-analysis method is used to compare the implementation of standard procedures being imposed in those selected universities. The comparisons show the similarities and distinguish the differences between them. Indeed, it is possible to determine the user-requirements in the building maintenance management process, which meets the main objective of this study. In order to make the analysis visible, the user-requirements for the building maintenance management process have been divided into five different stages, which are medium of request, requestor information, defect or failure information, information to maintenance staff and the post-maintenance process. Users in each stage might be different as the requestor might be a layman while the maintenance staff may have a good technical background. All information related to these five stages was then collected and analysed as shown in Table 2, following. 
Table 2: Cross-analysis of User-requirements in the Building Maintenance Management Process.

\begin{tabular}{|c|c|c|c|c|}
\hline Item Description & 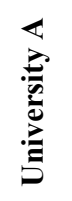 & 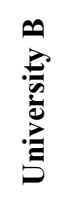 & 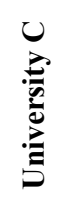 & 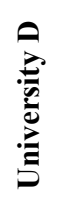 \\
\hline \multicolumn{5}{|l|}{ Medium of Request } \\
\hline Fax / Email / Letter / Request Form & & & & $\mathrm{x}$ \\
\hline Website / Online & $\mathrm{x}$ & $\mathrm{x}$ & $\mathrm{x}$ & \\
\hline Walk in & $\mathrm{x}$ & $\mathrm{x}$ & $\mathrm{x}$ & $\mathrm{x}$ \\
\hline Telephone & $\mathrm{x}$ & $\mathrm{x}$ & $\mathrm{x}$ & $\mathrm{x}$ \\
\hline Smartphone Application (WhatsApp) & & & $\mathrm{x}$ & \\
\hline \multicolumn{5}{|l|}{ Requestor Information } \\
\hline Name & $\mathrm{x}$ & $\mathrm{x}$ & $\mathrm{x}$ & $\mathrm{x}$ \\
\hline ID Number & & $\mathrm{x}$ & $\mathrm{x}$ & \\
\hline Witness & $\mathrm{x}$ & & & \\
\hline Position & & & $\mathrm{x}$ & \\
\hline Date \& Time & $\mathrm{x}$ & & & $\mathrm{x}$ \\
\hline Faculty / Department & $\mathrm{x}$ & $\mathrm{x}$ & $\mathrm{x}$ & $\mathrm{x}$ \\
\hline Building ID, Room ID, Floor ID & & & $\mathrm{x}$ & \\
\hline Telephone number & $\mathrm{x}$ & $\mathrm{x}$ & $\mathrm{x}$ & $\mathrm{x}$ \\
\hline Email & & $\mathrm{x}$ & $\mathrm{x}$ & \\
\hline \multicolumn{5}{|l|}{ Defect or Failure Information } \\
\hline State / Campus / Space & & $\mathrm{x}$ & & \\
\hline Name of Building (List Provided Yes/No) & Yes & No & Yes & No \\
\hline Block (List Provided Yes/No) & Yes & No & Yes & No \\
\hline Level (List Provided Yes/No) & Yes & No & Yes & No \\
\hline Location (Description) & $\mathrm{x}$ & & & $\mathrm{x}$ \\
\hline No. of Room (List Provided Yes/No) & No & No & Yes & No \\
\hline Category of Defect or Failure (List Provided Yes/No) & Yes & Yes & Yes & No \\
\hline Type of Defect or Failure (List Provided Yes/No) & Yes & Yes & Yes & Yes \\
\hline Description & $\mathrm{x}$ & $\mathrm{x}$ & $\mathrm{x}$ & $\mathrm{x}$ \\
\hline \multicolumn{5}{|l|}{ Information to Maintenance Staff } \\
\hline Reference Number / Service ID & $\mathrm{x}$ & $\mathrm{x}$ & $\mathrm{x}$ & $\mathrm{x}$ \\
\hline Work Request ID / Work Order ID & & & $\mathrm{x}$ & \\
\hline Name of Staff & $\mathrm{x}$ & $\mathrm{x}$ & $\mathrm{x}$ & $\mathrm{x}$ \\
\hline Staff Contact Number / Job Position & & $\mathrm{x}$ & & \\
\hline Scope of Work & $\mathrm{x}$ & $\mathrm{x}$ & & $\mathrm{x}$ \\
\hline Name of Contractor & $\mathrm{x}$ & $\mathrm{x}$ & $\mathrm{x}$ & $\mathrm{x}$ \\
\hline Status of Job & $\mathrm{x}$ & $\mathrm{x}$ & $\mathrm{x}$ & \\
\hline Verification & & $\mathrm{x}$ & $\mathrm{x}$ & $\mathrm{x}$ \\
\hline Date Start & $\mathrm{x}$ & $\mathrm{x}$ & $\mathrm{x}$ & $\mathrm{x}$ \\
\hline Time Start & $\mathrm{x}$ & $\mathrm{x}$ & $\mathrm{x}$ & $\mathrm{x}$ \\
\hline Date \& Time Finish & $\mathrm{x}$ & & $\mathrm{x}$ & \\
\hline Total Hours & $\mathrm{x}$ & & $\mathrm{x}$ & \\
\hline Work Description & $\mathrm{x}$ & $\mathrm{x}$ & $\mathrm{x}$ & $\mathrm{x}$ \\
\hline Cause of Defect or failure & $\mathrm{x}$ & & & \\
\hline Name, Quantity and Price of Spare Parts & $\mathrm{x}$ & & & \\
\hline Total Cost & $\mathrm{x}$ & & & \\
\hline \multicolumn{5}{|l|}{ Post Maintenance Process } \\
\hline Client Feedback & $\mathrm{x}$ & $\mathrm{x}$ & $\mathrm{x}$ & $\mathrm{x}$ \\
\hline Survey Form & & $\mathrm{x}$ & $\mathrm{x}$ & \\
\hline Job Statistics/ Job Status/ Job Category & $\mathrm{x}$ & $\mathrm{x}$ & $\mathrm{x}$ & $\mathrm{x}$ \\
\hline
\end{tabular}

\section{Discussion}

The main discussion of the cross-analysis results is focused on the similarities between the building maintenance management processes in all four selected universities. These similarities show the important user-requirements needed for building maintenance management practices. An analysis of 57 elements from the five sub-topics is shown in Table 3 and identifies 17 (30\%) of the elements that have similar aspects. 
Table 3: The Similar Aspects in Building Maintenance Management Elements

\begin{tabular}{|l|l|l|}
\hline Medium of Request & Defect or Failure Information & Information to Maintenance Staff \\
\hline Walk in & Types of defect or failure & Reference number / service ID \\
\hline Telephone & Descriptions & Name of staff \\
\hline & & Name of contractor \\
\hline Requestor Information & Post-maintenance Process & Date start \\
\hline Name & Client feedback & Time start \\
\hline Faculty / Department & Job status & Work description \\
\hline Telephone number & Job categories & \\
\hline & Job statistics & \\
\hline
\end{tabular}

Seventeen (17) out of fifty seven (57) elements can be considered as basic elements or minimum requirements as they are essential to ensure that the maintenance management process could be implemented by using a computer application or manually. $42 \%$ of the elements are found to be complicated or with only a single application throughout the maintenance management processes of the four universities as shown in Table 4, following:

Table 4: The Single Application Elements Throughout the Maintenance Management Processes

\begin{tabular}{|l|l|l|}
\hline Medium of Request & Defect or Failure Information & Information to Maintenance Staff \\
\hline Fax & State & Work request ID \\
\hline Email & Campus & Work order ID \\
\hline Smartphone applications & Space & Staff contact number \\
\hline Letter & & Job position \\
\hline Request form & Requestor Information & Cause of Defect or Failure \\
\hline & Witness & Name of Spare Parts \\
\hline Post Maintenance Process & Position & Quantity \\
\hline Survey form & Building ID & Price of Spare Part \\
\hline & Room ID & Total Cost \\
\hline & Floor ID & \\
\hline
\end{tabular}

From the result of the pilot study it could be suggested that 24 aspects which have been considered to be complicated have become surplus to the elements of the maintenance management processes as they only support the available basic elements. However, each of the universities has its own reasons for having these elements in their maintenance practices. For example, University D carries out its maintenance practices manually, thus they need fax, email, letter and request forms as their medium of request. Meanwhile, University $\mathrm{C}$ has proper building data, thus they request such details as Building ID, Room ID and Floor ID in order to ensure the accuracy of the work being carried out. As for University B, the huge number of campuses all over Malaysia requires the detail of state, campus and space on their defect or failure information. In University A, the details on aspects of the causes of defect or failure, name of spare parts, quantity of spare parts, price of spare parts and total cost are for their own records.

\section{Conclusion}

All higher education institutions share common criteria of good practices in building maintenance although the different practices allow them to be flexible in implementing the building maintenance process. The cross-analysis has shown that all the participating universities share some important criteria while implementing building maintenance management processes. Even though there is some gap between the universities during the implementation, the core business remains the same. It can also be concluded that with the great effort required to develop such systems may lead to a high-end and sophisticated well-maintained building environment. Finally, the user-requirements from this pilot study will be a stepping stone in developing an efficient method of managing the building maintenance with customisable elements that suit each organisation and bring benefits to the stakeholders. From this pilot study, all data regarding user-requirements will be analysed to support an extensive study involving all Malaysian higher education institutions.

\section{Acknowledgement}

This work was financially supported by the National Institute of Valuation, Malaysia, under the National Real Estate Coordinator (NAPREC) research grant (UTM grant no: 4B086). 


\section{References}

[1] (UK) British Standards Institution, BS 8536:2010 Facility Management Briefing. Code of Practice. Published October 2010.

[2] Mustapa, S. A. H. S. and Adnan, H. (2008) Facility Management Challenges and Opportunities in the Malaysian Property Sector. Journal of Sustainable Development, 1, (2): pp. 79-85.

[3] Abdullah, S. (2011) Managing Government Property Assets: The Main Issues from the Malaysian Perspective, Journal of Techno-Social | ISSN 2229-8940 | Vol. 3 No. 1 April.

[4] Lateef, O. A., Khamidi, M. F. and Idrus, A. (2010) 'Building maintenance management in a Malaysian university campuses: a case study', Australasian Journal of Construction Economics and Building, 10 (1/2) 76-89.

[5] Löfgren, A. (2007) Mobility In-site: Implementing Mobile Computing in a Construction Enterprise. The Communications of the Association for Information Systems, 20 (37), 1-12.

[6] Šuman, N. \& Pšunder, M. (2008) Mobile Computing Changing the Traditional Ways of Organizing the Construction Company. American Journal of Applied Sciences, 5 (1), 42-47.

[7] Nieswiadomy, R.M. (2002). Foundations of nursing research (4th ed.). Upper Saddle River, NJ: Pearson Education.

[8] Lackey, N.R. \&Wingate, A.L. (1998). The pilot study: One key to research success. In P.J. Brink \& M.J. Wood (Eds.), Advanced design in nursing research (2nd ed.). Thousand Oaks, CA: Sage.

[9] Cohen, D., Crabtree, B. (2006). "Qualitative Research Guidelines Project." Retrieved online at http://www.qualres.org/HomeSemi-3629.html. Accessed 25th August 2014.

[10] Newton, N. (2010). The use of semi-structured interviews in qualitative research: strengths and weaknesses. Paper submitted in part completion of the requirements of the degree of Doctor of Philosophy, University of Bristol. Retrieved online at http://www.academia.edu/1561689/ Accessed 25th August 2014.

[11] Banfield, G. (2004). 'What's Really Wrong with Ethnography?' International Education Journal 4(2): 53-63. 